\title{
Overview of the Usage of Some Turkicisms from Albanian Language Students at the University of Prizren "Ukshin Hoti" in Prizren
}

\author{
Albulena PLLANA BREZNICA ${ }^{1}$
}

\author{
Fisnike PLLANA ${ }^{2}$
}

\author{
Manuscript information: \\ Received: April 20, 2019 \\ Revised: August 13, 2019 \\ Accepted: September 07, 2019
}

\section{Author 1}

MA, Department of Albanian Language, University of Prizren "UKSHIN HOTI", Prizren, Republic of Kosova E-mail: aalbulena.p@gmail.com

\section{Author 2}

BA, Department of English Language and Literature, University of Prishtina "HASAN PRISHTINA" Prishtina, Republic of Kosova E-mail: fisnike_p@gmail.com

\section{Author 3}

Department of German Language and Literature, University of Prizren "UKSHIN HOTI", Prizren, Republic of Kosova E-mail: zanzi96@hotmail.com

\begin{abstract}
The Albanian language, as well as the other Balkan languages, have received a large number of Turkish language elements, first of them being the acceptance of Turkish words. These words, respectively the Turkicisms, have penetrated in almost all spheres in the fields of social life. In Albanian, there are many words in these social spheres: religious spheres, administrative spheres, military spheres, crafts, construction, home environment, names etc. The historical and linguistic conditions of the borrowing of Turkicisms are known. Albanians and Turks (Ottomans) got into contact in the wars and battles between them, as well as during the reign of the Turkish Empire in the Balkan Peninsula, and in the Albanian territories as well. Turkicisms began to enter the Albanian language from the time the Turks deployed military officers and clerks in several Albanian cities. The ruling period of the foreign invaders and the typology of the communicating languages had a huge influence on linguistic borrowings. The Albanian language is typologically quite remote from Turkish and has therefore assumed relatively few Turkicisms compared to the long period of Turkish rule in the Albanian area. For this purpose, this research and analysis method has been used: A survey was carried out with 60 students of the Department of Albanian Language and Literature at the University of Prizren "Ukshin Hoti" in Prizren, with first year students of the second semester and with second year students of the second semester. In the analysis of the tests, graphical presentations of the use of some Turkish words (Turkicisms) have been created, which are used by students in conversations with each other, in the family and in society, in the city and around Prizren.
\end{abstract}

Keywords: Albanian language, borrowings, Turkish borrowings, Turkicisms in the Albanian language. 


\section{Überblick Über Die Verwendung Einiger Turkizismen Von Studenten Der Albanischen Sprache An Der Universität "Ukshin Hoti” In Prizren}

\section{Zusammenfassung}

Sowohl die albanische als auch die anderen Balkan-Sprachen haben zahlreiche Elemente der türkischen Sprache erhalten, vor allem die Akzeptanz türkischer Wörter. Diese Wörter bzw. die Turkizismen haben in fast allen Bereichen des gesellschaftlichen Lebens Einzug gehalten. Auf Albanisch gibt es viele Wörter in diesen sozialen Bereichen: religiöse Bereiche, administrative Bereiche, militärische Bereiche, Handwerk, Bauwesen, häusliche Umgebung, Namen usw. Die historischen und sprachlichen Bedingungen der Entlehnung von Turkizismen sind bekannt. Albaner und Türken (Osmanen) kamen in den Kriegen und Schlachten untereinander sowie während der Herrschaft des türkischen Reiches auf der Balkanhalbinsel und in den albanischen Gebieten in Kontakt. Seit der Zeit, als die Türken in mehreren albanischen Städten Offiziere und Militärangehörige stationiert hatten, begannen die Turkizismen in die albanische Sprache einzudringen. Die herrschende Zeit der ausländischen Invasoren und die Typologie der kommunizierenden Sprachen hatten einen großen Einfluss auf die sprachlichen Entlehnungen. Die albanische Sprache ist typologisch weit von der türkischen Sprache entfernt und hat daher im Vergleich zu der langen türkischen Herrschaft im albanischen Raum relativ wenige Turkizismen angenommen. Zu diesem Zweck wurde diese Forschungs- und Analysemethode verwendet: Es wurde eine Umfrage mit 60 Studenten der Abteilung für Albanische Sprache und Literatur der Universität Prizren "Ukshin Hoti" in Prizren, mit Studenten des ersten Jahres des zweiten Semesters und mit Studenten des zweiten Jahres des zweiten Semesters durchgeführt. Bei der Analyse der Tests wurden grafische Darstellungen der Verwendung einiger türkischen Wörter (Turkizismen) erstellt, die von Studenten in Gesprächen untereinander, in der Familie und in der Gesellschaft, in der Stadt und in der Umgebung von Prizren verwendet werden.

Schlüsselwörter: Albanische Sprache, Entlehnungen, türkische Entlehnungen, Turkizismen in der albanischen Sprache.

Cite as:

Pllana Breznica, A.; Pllana, F. \& Pllana, Z. (2019). Overview of the Usage of Some Turkicisms from Albanian Language Students at the University of Prizren "Ukshin Hoti" in Prizren. European Journal of Educational and Social Sciences, 4 (2), $73-83$. 


\section{INTRODUCTION}

In order to realize this paper we used the works of some Albanian linguists, who have published works on Orientalism's and Turkish loanwords, in national and international conferences in the Albanian language. Many Albanian and foreign linguists have been studying Orientalism's and Turkish loanwords: K. Ashta, A.Kostallari, E. Çabej, M. Samara, T. Dizdari, Xh. Lloshi, L. Mulaku, L. Latifi, U. Harri, F. Miklosich, N. Boretzky and others. We also used Albanian language dictionaries such as: "Fjalor $i$ gjuhës shqipe (Albanian Language Dictionary)" (1954), Tirana, " Fjalor i gjuhës së sotme shqipe (Contemporary Albanian Dictionary)" (1980), Tirana and "Fjalor $i$ gjuhës shqipe (Albanian Dictionary) “ (2006) , Tirana.

Based on T. Dizdar's "Fjalor i Orientalizmave (Dictionary of Orientalisms)" [Harri 2015: 5], the Albanian language has borrowed about 4,406 words, of which about 1,800 were included in the "Fjalor $i$ Gjuhës së Sotme Shqipe (Contemporary Albanian Dictionary)" (1980). Studies on Turkish borrowings in the Albanian language began in the second half of the 19th century [Harri 2015: 7]. Gustav Meyer, points out that 1180 Turkish loanwords are in his Dictionary of 5140 words. In the "Fjalor $i$ orientalizmave (Dictionary of Orientalisms)" of the Albanian scholar T. Dizdari there are 4406 direct Turkish borrowings, which is one of the most important scientific works in the field of Turkicisms, not only in the Albanian area but also in the whole Balkans. Dizdari gives for every Turkish borrowing the correspondent word in the Turkish language, as well as the origin of the word following the traces of Turkish connection with other Oriental languages (Arabic, Persian).

\section{Orientalisms or Turkish borrowings?}

It is a fact that there is disagreement between the terminologies used by some authors. Before the 1960s, a part of Turkish scholars and Balkan linguists tried to use the term "turqizma (Turkicisms)" for all words taken from the Turkish language, regardless of their Arab, Persian, or Turkish etymology [Harri 2015:18]. The researcher L. Latifi considers the use of the term "orientalism" instead of the term "turqizma (Turkicisms)" as an error; starting from the fact that Balkan people have never had direct contact with the Arabs or Persians. The Balkan people have lived together for 500 consecutive years with the Ottomans, so the Turkish language was the language of communication within the Ottoman Empire. The words taken from Turkish were transmitted into the languages of Balkan as they were used in Turkish by altering and ultimately wiping out the features of Arabic or Persian languages.

Because of the already known historical circumstances, the Balkan languages first have borrowed words that previously expressed unknown meanings and notions. These words have been accepted and have begun to be absorbed in mass as they were used in the everyday social and administrative life; therefore the words introduced in the Albanian language, but also in other Balkan languages, are taken from the Turkish language.

\section{Turkish borrowings in the Contemporary Albanian Dictionary}

In the "Contemporary Albanian Dictionary" (Fjalori $i$ Gjuhës së Sotme Shqipe) of 1980, about 1800 Turkish borrowings are included. A number of Turkish loanwords are classified 
as part of conversational speech, while another number are active only when used for literary purposes. Below we mention some borrowings that contain the largest number of Turkish loanwords:

a) Denomination by professions: argat, bakërxhi, berber, bojaxhi, çifçi, hamall, kafexhi, kazanxhi, kundraxhi, padishan, qatip, sahlepçi, tenekexhi, tuxhar, vezir etj.

b) Military terminology: alltie, asqer, barut, bashibozuk, bedel, bylykbash, çaush, çifte, dyrby, gjyle, janiçer, jatagan, kobure, kundak, nagan, nishan, nishanxhi, patllak, saçme, topuz etj.

c) Terminology of household appliances: bardak, çanak, çarçaf, divan, dollap, dyshek, fener, fitil, gygym, ibrik, jastëk, jorgan, kandil, legen, mangall, qilim, sahan, saksi, sepet, shilte, sofra, tabaka, tepsi, xhezve, zinxhir etj.

d) Terminology of various foods and meals: ashure, bakllava, bostan, boza, çaj, çorba, jahni,musaka, paça, pastërma, qofte, reçel, sheqer, turshi etj.

e) Clothing terminology: astar, basma, çadër, çanta, çizme, çorap, dimi, gjerdan, jaka, jelek, mendil, shami, xhamadan etj.

f) Religious terminology: abdest, Allah, bajram, dervish, dua, haxhi, haxhillëk, hoxha, iftar, imam, kuran, minare, namaz, ramazan, sure, syfyr, teqe, tespih, tyrbe, xhami, xhenet etj.

g) Terminology on the qualities of the individual: adash, asgan, beqar, dallaverexhi, dilenxhi, effendi, hajdut, jaran, kopuk, matuf, merakli, muhaxhir, sarhosh, tamahqar, topall etj. h) Terminology with social life: amanet, haber, hajër, hallall, haram, hile, hyzmet, kasavet, kimet, mukajet, myzhde, peshqesh, qejf, ryshfet, selam, sevap, zarar, zor etj

i) Administrative terminology: haraç, kanun, kaza, mahalle, mylk, pashallëk, post, sanxhak, vergi, vilajet, yshyr, zarf etj.

j) Construction terminology: ahur, baxha, bodrum, çardak, çati, çeshme, dysheme, karabina, kat, konak, kubbe, mazgall, mertek, oda, oxhak, penxhere, qerpiç, qilar, qireç, shadërvan, tavan, trapazan, tullaulluk, xham etj.

\section{Turkicisms at the old Albanian authors}

In the first book in Albanian, "Meshari" (1555) of Gj. Buzuku five Turkish loanwords are used [Pllana 2017: 80], in P. Budi (1618) a bit more, and in F. Bardhi (1635) about 75 Turkicisms [Pllana 2017: 86-97]. In P. Bogdani (1685) there are more turkish loanwords used than in the works of his predecessors [Mulaku 2017: 92]. The second period of Turkish borrowings is during the 18th and 19th centuries until 1912.

\section{Research Methodology}

The Analytical Method:_This method was used for the survey carried out with 60 students of the Department of Albanian Language and Literature at the University of Prizren "Ukshin Hoti" in Prizren, with first year students of the second semester and with second year students of the fourth semester. In order to have an idea about the use of Turkish loanwords, students of the Department of Albanian Language and Literature at the University of Prizren "Ukshin Hoti" in 
Prizren, 60 (sixty) students helped by filling in surveys. This way we collected the data presented in this research for the 2018/2019 academic year, the 2019 summer semester for the number of Turkish loanwords (we have selected 70 Turkish loanwords for this

The first group of words (Turkish loanwords):

$\begin{array}{llll}\text { aksham (akşam) } & \text { bereqet(bereket) } & \text { dushman(düşman) } & \text { hazër(hazir) } \\ \text { amanet(emanet) } & \text { birinxhi(birinci) } & \text { dynja(dünya) } & \text { hyzmeqar(hyzmetkâr) } \\ \text { argat (irgat) } & \text { bylyzyk(bilezik) } & \text { evlat(evlât) } & \text { jazëk(yazik) } \\ \text { ashiqare(aşikâre) } & \text { çardak(çardak) } & \text { frëngi(frengi) } & \text { kabull(kabul) } \\ \text { axhami(acemi) } & \text { çekmexhe(çekmece) } & \text { gajret(gayret) } & \text { kadi(kadi) } \\ \text { bahçe(bahçe) } & \text { çrak(çirak) } & \text { haber(haber) } & \text { kandar(kantar) } \\ \text { bajram(bayram) } & \text { dallkauk(dalkavuk) } & \text { hanëm(hanim) } & \text { kasap(kasap) } \\ \text { bela(belâ) } & \text { dert(dert) } & \text { hava(hava) } & \text { kaza(kaza) } \\ \text { kodosh(kodoş) } & & & \\ \text { komshi(komşu) } & & & \end{array}$

research, which we have considered as more frequently used, usually used during family and friends conversations. 
Research results of 30 (thirty) first year students, during the 2018/2019 academic year, 2019 summer semester, for the first group of words (Turkish loanwords):

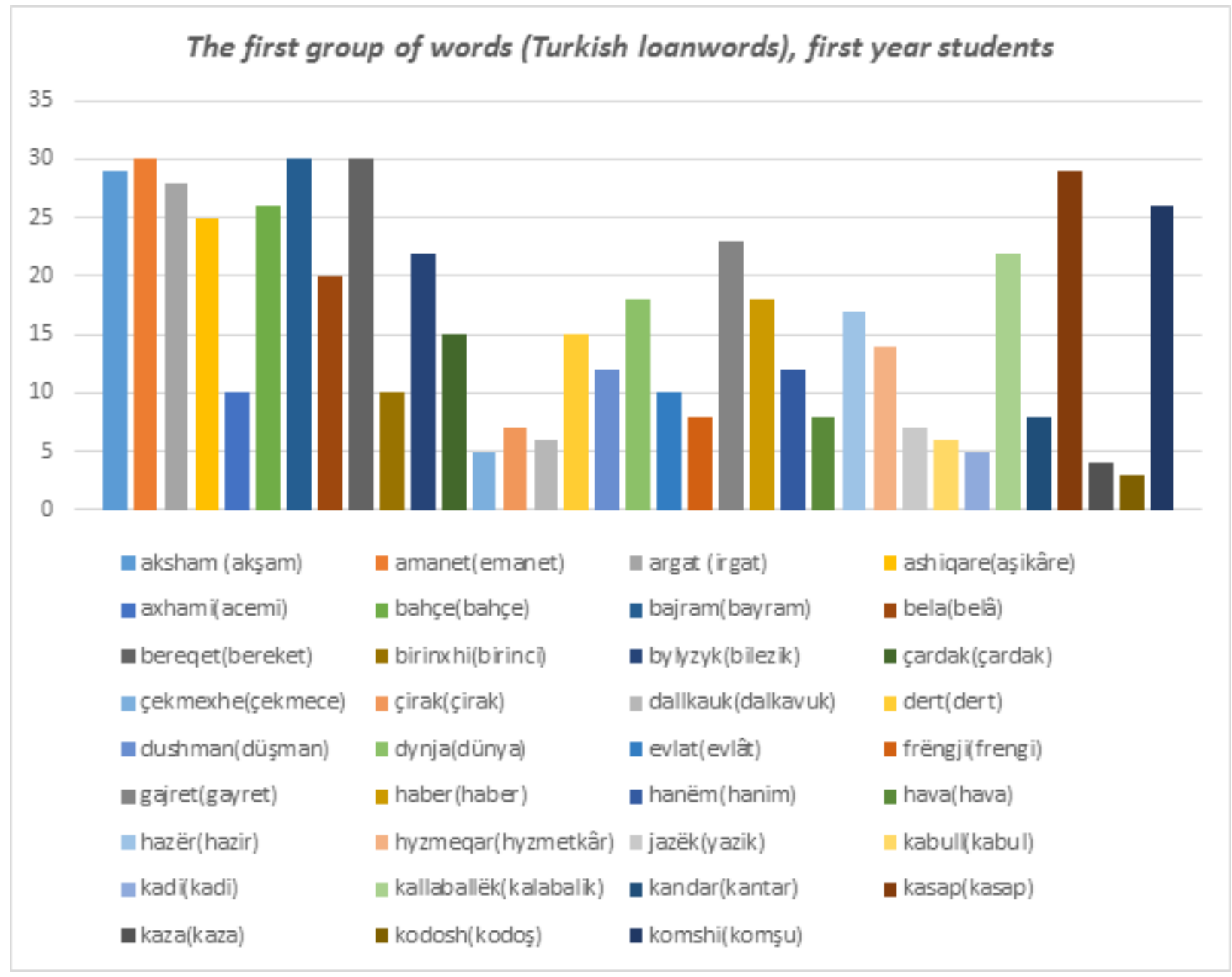

Research results of 30 (thirty) second year students, during the 2018/2019 academic year, 2019 summer semester, for the first group of words (Turkish loanwords): 


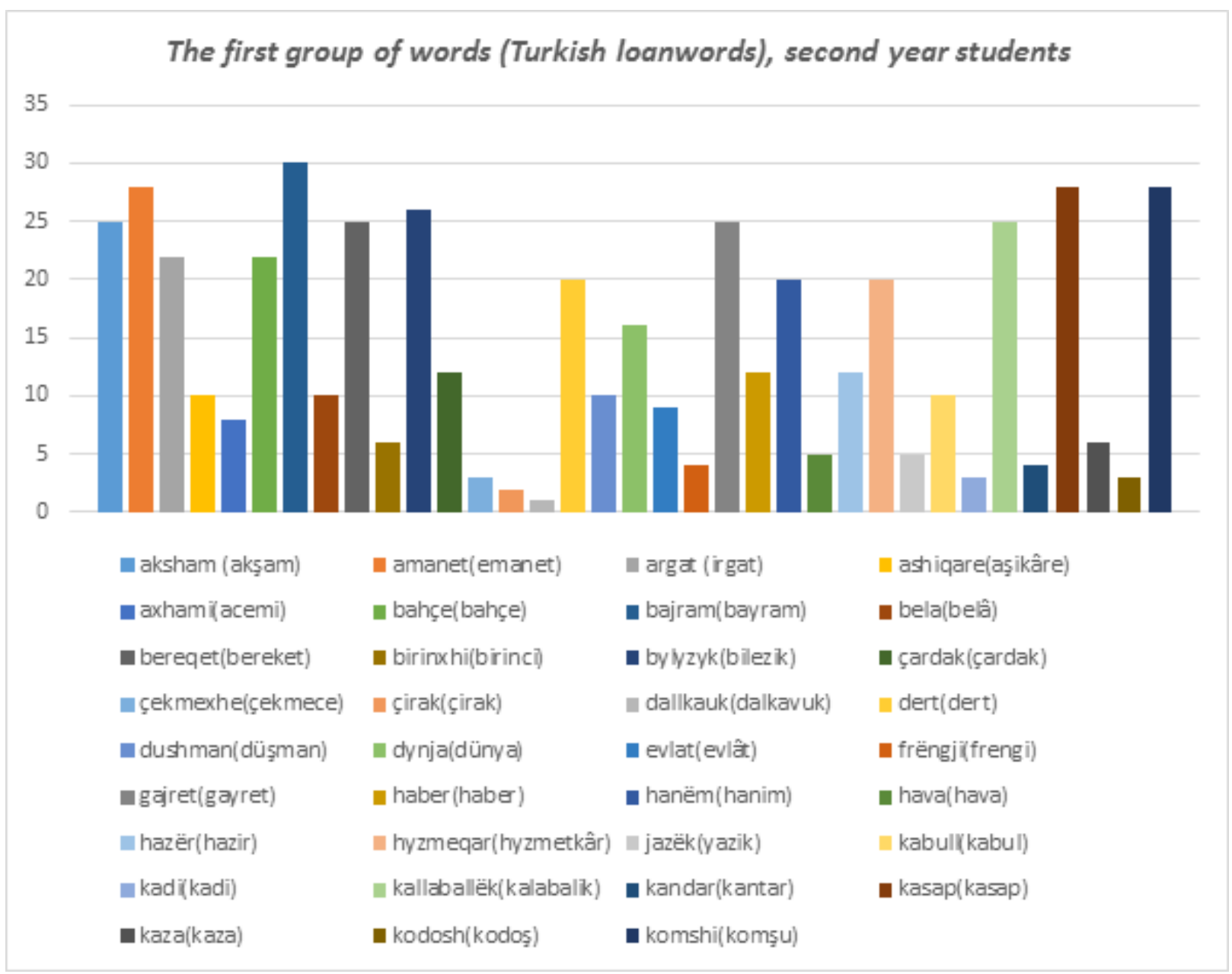

The second group of words (Turkish loanwords):

$\begin{array}{llll}\text { kube(kubbe) } & \text { pazar(pazar) } & \text { shejtan(şeytan) } & \text { zengjin(zengin) } \\ \text { kusur(kusur) } & \text { pehriz(perhiz) } & \text { tabiat(tabiat) } & \text { zift(zift) } \\ \text { lezet(Lezzet) } & \text { qatip(kâtip) } & \text { tebeshir(tebeşir) } & \text { zijafet(ziyafet) } \\ \text { llagap(lâkap) } & \text { qemer(kemer) } & \text { terezi(terazi) } & \text { zullum(zulüm) } \\ \text { majhosh(mayhoş) } & \text { qymez(kümes) } & \text { terzi(terzi) } & \text { zymbyl(sümbül) } \\ \text { mavi(mavi) } & \text { qyryk(kütük) } & \text { topuz(topuz) } & \\ \text { melhem(melhem) } & \text { rushfet(rüşvet) } & \text { xhade(cadde) } & \\ \text { milet(millet) } & \text { safi(safi) } & \text { xhambaz(cambaz) } & \\ \text { mukajet(mukayese) } & \text { satër(satir) } & \text { xhevap(cevap) } & \\ \text { myzhde(müjde) } & \text { sehir(seyir) } & \text { zahmet(zahmet) } & \end{array}$


Research results of 30 (thirty) first year students, during the 2018/2019 academic year, 2019 summer semester, for the second group of words (Turkish loanwords):

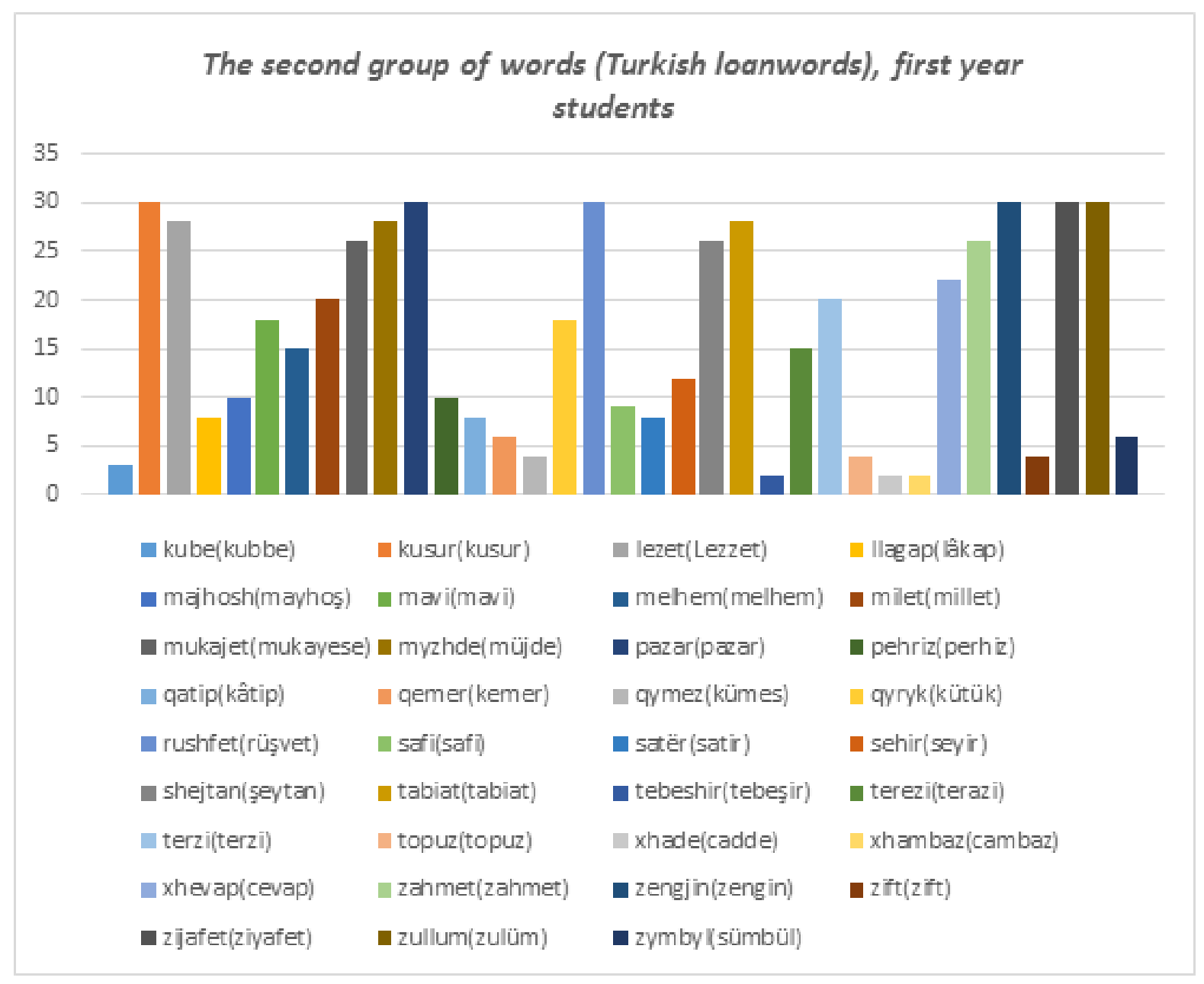

Research results of 30 (thirty) second year students, during the 2018/2019 academic year, 2019 summer semester, for the second group of words (Turkish loanwords): 


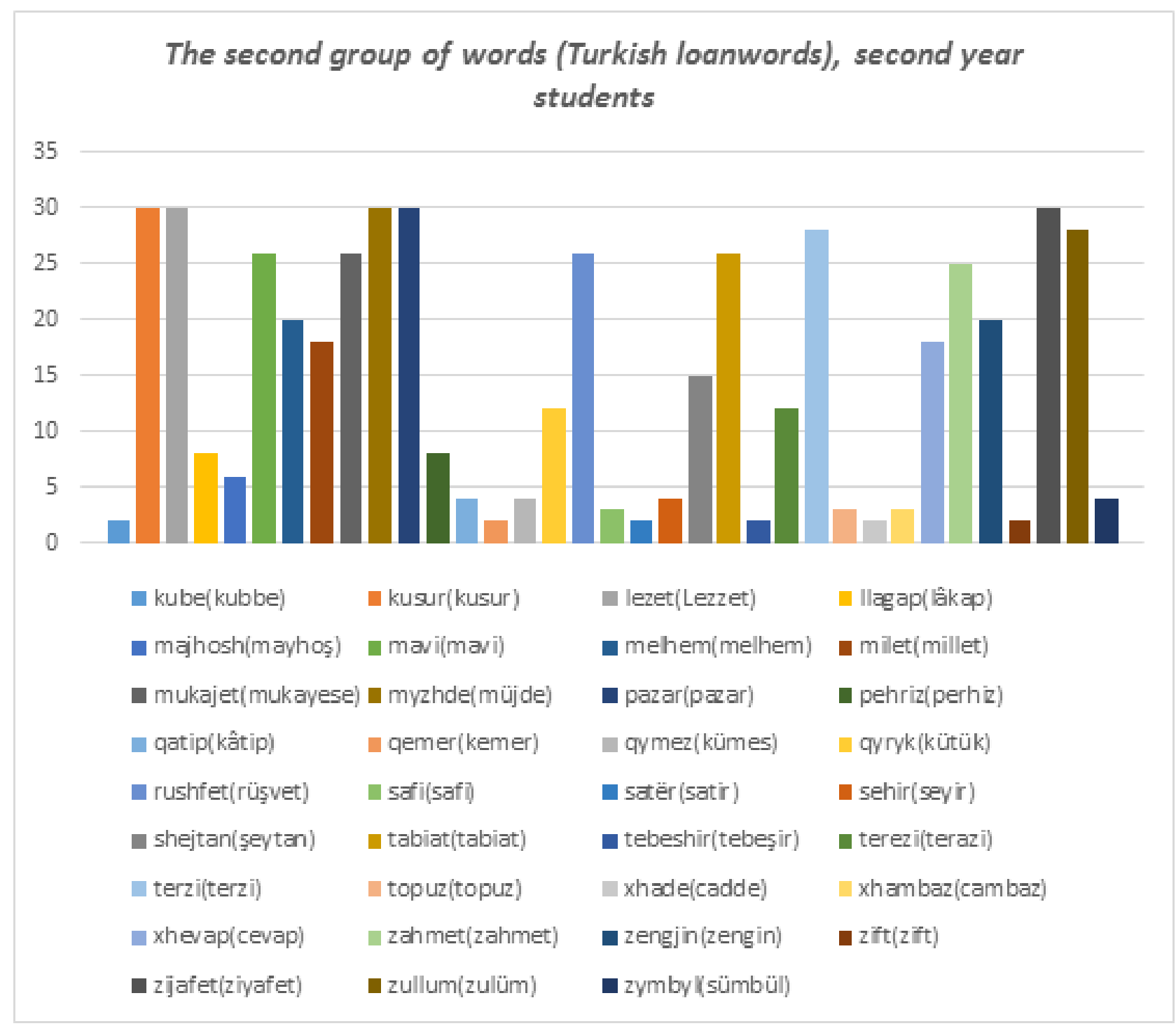

\section{CONCLUSION}

It is generally known that the Turkish language has been one of the most important sources of enriching the vocabulary of the Balkan languages during the five centuries of the Ottoman rule, so the Balkan languages have given and taken words from each other.

Turkish borrowings are so uniformly distributed in Balkan languages that a considerable number of them can be defined as "Balkan Turkish loanwords." The borrowed words, got attached to literature, religious language, administrative documents and other written texts.

The initially borrowed words through the spoken language were in fact borrowed from Turkish dialects spoken in the Balkan region. It was not a pure Turkish language usage and there were significant differences from Istanbul Turkish, on which the Turkish literary language was raised.

In the "Fjalori $i$ Sotëm $i$ Gjuhës Shqipe" (Contemporary Albanian Dictionary), about 1800 Turkish loanwords have been included. A number of Turkish loanwords are classified 
as part of conversational speech, while another number are active only when used for literary purposes.

The research results of 30 (thirty) students of the first and second year, during the 2018/2019 academic year, the 2019 summer semester, for 70 words (Turkish loanwords) used in everyday life, are presented in the diagrams.

\section{REFERENCES}

Ashta, K. (1996): “Leksiku historik i gjuhës shqipe”, Universiteti i Shkodrës “Luigj Gurakuqi”, Shkodër. Boretzky, N. (1975): "Der türkischen Einfluss auf das Albanische“, Teil I: Phonologie und Morphologie der albanische Turzismen, Wiesbaden.

Boretzky, N. (1976): "Der turkische Einfluss auf das Albanische, Teil 2: Wörterbuch der albanischen Turzismen", Wiesbaden.

Çabej, E. (1975): "Për një shtresim kronologjik të huzimeve turke në shqipe", "Sf", nr. 1, Tiranë.

Dizdari, T (2006): “Fjalor i Orientalizmave”, Tiranë.

"Fjalor i gjuhës shqipe" (1954), Tiranë.

“Fjalor i gjuhës së sotme shqipe” (1980), Tiranë.

"Fjalor i gjuhës shqipe" (2006), Tiranë.

Halimi, M. (1993): “Ndikimi i orientalizmave në fushën e fjalëformimit ndër të folmet shqipe”, Prishtinë.

Harri, U. (2015): “Veçori të turqizmave në gjuhën sheipe përmes "Fjalorit të orientalizmave” të Tahir Dizdarit”, dis., UT FGJH, Tiranë.

Hoxha, Sh. (2015): “Fjalor fjalësh e shprehjesh turke”, Prishtinë.

Kostallari, A. (1978): "Rreth depërtimit të turqizmave në gjuhën shqipe gjatë shekujve XVII-XVIII", në "Gjurmime albanologjike“, SSHF, Prishtinë.

Latifi, (Xhamari) L. (2006):” Huazimet turke në shqipe krahasuar me gjuhët e tjera të Ballkanit”, Tiranë. Lloshi, Xh. (2013): “Orientalizmi i padëshirauar i shqipes”, Gazeta ”Dita”, 8 Mars, Tiranë.

Mehdiu, F. (1978): “Orientalizmat, hyrja dhe përdorimi i tyre në gjuhën shqipe”, Jehona 7, Shkup.

Mulaku, L. (2017): “Studime gjuhësore”, IA, Prishtinë.

Ndreca, M. (1986): “Fjalor fjalësh e shprehjesh të huaja”, Prishtinë.

Nuhiu, V. (1990): “Ndikimet ndërgjuhësore”, RILINDJA, Prishtinë.

Pllana, (Breznica) A. \& Pllana, F. (2018): "Vështrim rreth përdorimit të anglicizmave tek nxënësit e shkollava të mesme të larta në Vushtrri", në KONFERENCA VII NDËRKOMBËTARE "KËRKIME GJUHËSORE” 20 korrik 2018, Tiranë.

Pllana, G. (2017): “Formimi i terminologjive teknike shqipe mbi bazën e leksikut të përgjithshëm”, QSA IGJL, Tiranë. 
Samara, M. (1995): "Zhvillime leksiko-semantike të turqizmave në gjuhën shqipe“, në "Sf", nr.1-4, Tiranë.

Thomai, J. (1995): “Terminologjia islame dhe leksikografia shqiptare”, Prishtinë. 